(C) С.С. Сніжко, 2018

УдК:616.27-002+616-06

\title{
Попередження поширення флегмон шиї у клітковину середостіння та розвитку гострого низхідного медіастиніту
}

\author{
С.С. Сніжко \\ snizhko.s@bigmir.net
}

Івано-Франківський національний медичний університет, Івано-Франківськ

\section{Реферат}

Проведено аналіз безпосередніх результатів лікування 43 хворих із глибокими флегмонами шиї, ускладненими гострим низхідним медіастинітом за 2014-2018 pр. Вік хворих від 21 до 72 років, в середньому 36,3 $\pm 3,9$ року. Для діагностики застосовували рентгенографію органів грудної клітки, ультрасонографію, комп'ютерну томографію, за показаннями фібробронхоскопію та фіброезофагогастродуоденоскопію. Одонтогенну флегмону шиї мали 19 (44,2\%) хворих, нагноєний лімфаденіт - 10 (23,2\%), тонзилогенну - 9 (20,9\%), гнійний тиреоїдит - 2 (4,6\%) хворих. Захворювання ускладнилося передньо-верхнім гострим низхідним медіастинітом - у $22(51,1 \%)$ хворих, верхнім у 7 (16,3\%), тотальним - у 14 (32,7\%). Встановлені діагностичні ознаки, які дозволяють запідозрити поширення гнійного процесу на середостіння. Запропоновано методику попередження поширення гнійної інфекції із міжфасціальних проміжків шиї у клітковину середостіння, яка полягає у ретростернальному інтрамедіастинальному введенні антибактеріальних середників. При використанні даної методики відзначали зниження частоти розвитку гострого гнійного медіастиніту, померли 7 (16,3\%) хворих.

Ключові слова: глибока флегмона шиї, гострий медіастиніт, хірургічне лікування

Surgical treatment of patients with neck phlegmon complicated acute descending mediastenitis Snizhko S.S.

Ivano-Frankivsk National Medical University, Ivano-Frankivsk

\section{Abstract}

The analysis of direct results of treatment of 43 patients with deep phlegmons of the neck complicated by acute downward mediastinitis for 2014-2018. The age of the patients from 21 to 72 years, on average $36.3 \pm 3.9$ years. For diagnostics, $\mathrm{X}$-ray of the chest organs, ultrasonography, computer tomography, according to indications of fibrobronchoscopy and fibroezofagogastroduodenoscopy were used. There were 19 (44.2\%) patients with odontogenic phlegmon, suppurated lymphadenitis- $10(23.2 \%)$, tonsilogen- $9(20.9 \%)$, purulent thyroiditis- $2(4.6 \%)$ patients. The disease was complicated by the anteriorupper acute downward mediastinitis in $22(51.1 \%)$ patients, the upper ones were 7 (16.3\%), total- $14(32.7 \%)$. Established diagnostic signs that allow you to suspect the spread of purulent process on the mediastinum. The method of preventing the spread of purulent infection from interfascial neck gaps in the mediastinal cell line, which consists in retrosternal intramedyal administration of antibacterial agents, is proposed. With the use of this technique, a decrease in the incidence of acute purulent mediastinitis was noted in $7(16.3 \%)$ patients.

Key words: deep phlegmon of neck, acute mediastinitis, surgical treatment

Вступ. Гнійно-некротичне запалення клітковини шиї - захворювання поліетіологічне і може траплятися в практиці загальних, торакальних хірургів, стоматологів, отоларингологів, ендокринологів та лікарів інших спеціальностей [1]. Супроводжуючись швидким розвитком набряку тканин шиї, трахеї, глибока флегмона шиї (ФШ) може поширюватися у клітковину середостіння з розвитком гострого низхідного медіастиніту (ГНМ), що призводить до виникнення синдрому системної запальної відповіді і сепсису та супроводжується численними ускладненнями, створюючи пряму загрозу життю хворого [3,4]. Безперервне переміщення органів середостіння (скорочення серця, пульсація судин середостіння, перистальтика стравоходу, рухи трахеї при кашлі, розмові) та розширення грудної стінки при диханні створюють умови для виникнення негативного тиску у клітковині середостіння, що сприяє швидкому розповсюдження гнійно-запального процесу із міжфасціальних проміжків шиї у середостіння із розвитком
ГНМ. При цьому відбувається зниження тиску у середостіння від верхніх його відділів донизу, до діафрагми. Так тиск у верхньому середостінні становить 0-5 мм вод. стовпчика, у нижньому середостінні - від - 5 до 20 мм вод. стовпчика.

Летальність у хворих при глибоких ФШ становить 1,9-8,4\%, при поширенні гнійника у клітковину середостіння летальність може сягати 17 $80 \%[2,3,5]$. За даними низки авторів, у хворих на ГНМ сепсис діагностують у 45-100\% випадків [2]. Тяжкість перебігу ГНМ обумовлена наявністю в середостінні центральних симпатичних та парасимпатичних нервів, важливих кровоносних та лімфатичних судин. Клітковина середостіння також інтенсивно всмоктує продукти розпаду тканин, що сприяє швидкому розвитку тяжкої інтоксикації $[1,4]$. Висока частота розвитку ГНМ спонукає хірургів до пошуку причин розвитку та шляхів поширення гнійного вмісту із просторів шиї у клітковину середостіння та методів їх профілактики. 
Таким чином, проблеми ранньої діагностики і лікування глибоких ФШ, залишаються актуальними. Особливу увагу представляє проблема попередження поширення гнійної інфекції із міжфасціальних проміжків шиї у клітковину середостіння.

Мета дослідження. Визначення причин виникнення флегмон шиї, вивчення шляхів поширення інфекції у клітковину середостіння та створення методики попередження потрапляння гнійної інфекції із клітковинних просторів шиї у середостіння.

Матеріали та методи. Впродовж 2014-2018 pp. на лікуванні в торакальному відділенні ІваноФранківської обласної клінічної лікарні знаходилося 43 хворих із ФШ та ГНМ. Вік хворих від 21 до 76 років, у середньому $36,3 \pm 3,9$ року. Чоловіків було $28(65,1 \%)$, жінок - 15 (34,9\%). Лівобічну ФШ мали $12(27,9 \%)$ хворих, правобічну - 19 $(44,2 \%)$, двобічну - 12 (27,9\%) пацієнтів. Серед найбільш частих причин, які викликали гнійний процес міжфасціальних шарів шиї одонтогенна ФШ встановлена у $19(44,2 \%)$ хворих, нагноєний лімфаденіт - у 10 (23,2\%), тонзилогенна ФШ - у 9 (20,9\%), гнійний тиреоїдит - у 2 (4,6\%), нагноєна кіста шиї, перфорація стравоходу, розрив трахеї - по одному хворому.

Найбільш часто гнійник на шиї розміщувався в spatium postviscerale - у $27(62,7 \%)$, в spatium praeviscerale - у $11(25,5 \%)$, у фасціальному проміжку m. sternocleidomastoidei - у 3 (6,9\%), в просторі позаду стравоходу - у 2 (4,6\%) хворих.

За несприятливого перебігу глибоких ФШ простежувався розвиток ГНМ, який діагностований нами у 12 (27,9\%) хворих. Для діагностики застосовували рентгенографію органів грудної клітки (ОГК), ультрасонографію (УСГ), комп’ютерну томографію (КТ) тканин шиї та середостіння, за показаннями фібробронхоскопію та фіброезофагогастродуоденоскопію. Сепсис діагностований у всіх хворих із ГНМ, пневмонії різних локалізацій - у 10 (83,3\%), емпієма плеври - у $8(66,7 \%)$, токсична анемія різного ступеня - у $8(66,7 \%)$, ексудативний плеврит - у 4 (33,3\%), гнійний перикардит - у 4 (33,3\%), респіраторний дистрес-синдром дорослих - у 3 (25\%) хворих.

Результати досліджень та їх обговорення. 3 високою достовірністю судити про стан клітковини середостіння дозволяла КТ, яку проводили у всіх хворих. За допомогою КТ виявляли наявність рідинних утворень на шиї, уточнювали їх локалізацію та розповсюдженість. Основними КТ діагностичними критеріями гострого медіастиніту вважали збільшення розмірів середостіння, набряк його клітковини, наявність у середостінні рідинних скупчень з різною щільністю за Хаунсфілдом та міхурців повітря. Непрямими ознаками гострого медіастиніту були наявність ексудату в перикарді та плевральних синусах.
УСГ застосували у всіх 43 хворих з флегмонами шиї для встановлення локалізації гнійників, їх поширеності та розмірів. Фібробронхоскопію провели у 5 (11,6\%) хворих при підозрі на пошкодження трахеї. У післяопераційному фібробронхоскопію широко застосовували для санації трахео-бронхіального дерева.

За нашими даними, прогностично несприятливими ознаками, які дозволяли запідозрити поширення гнійного процесу з шиї на середостіння були: поява ексудату у плевральних порожнинах - у 12 (100\%) хворих, у перикарді - у 4 (33,3\%) хворих, поширення набряку та гіперемії шкіри на нижню третину шиї та грудну клітку - у 3 (25\%), зменшення набряку тканин шиї при прориві гнійника у середостіння - у 2 (16,6\%), а також різке погіршення загального стану та наростання ознак гнійної інтоксикації.

При діагностованій глибокій ФШ, ускладненій ГНМ, всі хворі були прооперовані. Хірургічна тактика в кожному окремому випадку залежала від причини виникнення гнійника, локалізації, шляхів поширення на міжфасціальні проміжки шиї та клітковину середостіння, характеру гнійного ураження та загального стану хворого. Хiрургічне лікування розпочинали з розкриття глибокої ФШ та дренування іiі міжфасціальних проміжків. Застосовували передньо-бокову цервікотомію за Разумовським. Шкіру, підшкірну клітковину і власну фасцію розсікали гострим шляхом, у більш глибокі шари тканин шиї проникали тупим шляхом. Розкриття глибоких міжфасціальних проміжків шиї проводили пошарово, згідно 3 анатомічними орієнтирами, після розкриття гнійника за найкоротшим шляхом, видаляли некротизовані тканини, розкривали гнійні кишені. Для забезпечення повноцінного дренування «по прямій лінії» накладали контрапертури, застосовували товсті дренажні поліхлорвінілові трубки до 1 см в діаметрі, тонкі мікроіригатори та гумові смужки.

Для запобігання розвитку ГНМ нами було запропоновано оригінальну методику інтрамедіастинального введення антибактеріальних середників (Патент України №105664). Метою даної методики було: створення нульового або позитивного внутрішньогрудного тиску для усунення присмоктуючої дії середостіння, що попереджує поширення гнійної інфекції із міжфасціальних проміжків шиї у клітковину середостіння. Другим важливим чинником інтрамедіастинального введення ліків $є$ створення антибактеріального бар'єру між гнійною ділянкою шиї і середостіння 3 метою попередження потрапляння гнійної інфекції у клітковину середостіння. Для інтрамедіастинального введення застосовували антибактеріальні середники, які запобігали поширенню інфекції, створювали місцеву антибактеріальну дію та відмежовували здорове середостіння від гнійної порожнини. Суть методики полягає у наступно- 
му: після завершення розкриття флегмони шиї в проекції яремної вирізки грудини чітко по серединній лінії на 0,5-1 см за методикою Казанцева проводили введення мікрокатетера за методом Сельдінгера у клітковину середостіння на глибину до 1 см нижче від задньої пластини грудини до середини рукоятки грудини.

Після введення катетера інтрамедіастинально крапельним методом вводимо розчин антибіотиків із розрахунку 1,0 грам антибіотика в 100-150 мл ізотонічного фізіологічного розчину протягом 2-3 годин. Даний об'єм розчину дозволяє вирівняти негативний внутрішньогрудний тиск у середостінні й усунути присмоктуючу дію середостіння. Враховуючи відсутність у середостінні будь-яких фасціальних перепон, інфузія протягом цього часу забезпечує розповсюдження антибіотику по всій клітковині середостіння, що створює виражений місцевий антибактеріальний ефект. Таке введення розчинів із антибіотиком проводили 2 рази на добу. Із антибактеріальних препаратів найбільш часто застосовували розчини цефалоспоринів 3-4 покоління із розрахунку 1,0 грама на одне введення.

Інтрамедіастинальне введення антибактеріальних середників проводилося у хворих у яких проведено розкриття низької флегмони шиї на рівні яремної вирізки. Даний метод було використано у 9 (20,9\%) хворих - група 1. При застосуванні методики інтрамедіастинального введення антибіотиків у $8(88,8 \%)$ із 9 хворих гнійний процес було ліквідовано на стадії флегмони шиї без поширення гнійного процесу у клітковину середостіння. Розвиток ГНМ спостерігали лише у 1 $(11,2 \%)$ хворого при низькій ФШ, у хворого із надмірною вагою та при пізній госпіталізації (більше 3-х днів від початку захворювання). У ретроспективній групі хворих - група 2 (34 хворих), у яких даний метод не був застосований, ФШ ускладнилася ГНМ у $11(32,3 \%)$ хворих. При цьому у групі 1 спостерігали значно кращі показники динаміки зниження ендогенної інтоксикації у порівнянні із групою хворих, яким цей метод не застосовували. Динаміку зниження ендогенної інтоксикації визначали за рівнем лейкоцитарного індексу інтоксикації (ЛІІ) за Кальф-Каліфом та шкалою оцінки ендогенної інтоксикації АРАСНЕ II. В групі хворих, де використовували методику інтрамедіастинального введення антибактеріальних середників вже на перший день після операції ЛІІ знизився майже втричі - 3 6,2 у.о до 2,1 у.о. 3 нормалізацією показника на 5-й день. В групі 2 ЛІІ на першу добу знизився з 6,1 до 3,2 у.о. і залишався підвищеним на 5-ту добу від дати операції на рівні 2,6 у.о. Подібна картина спостерігалася і за шкалою оцінки важкості ендотоксикозу АРАCHЕ II. Так, до операції у групі 1 індекс ендогенної інтоксикації становив 17, на першу добу відзначено його зниження до 9 з норалізацією показника на 5-ту добу від часу операції. В групі 2 до операції індекс АРАСНЕ II становив 18 , на першу добу відзначали його зниження до 14, на 5-ту добу від операції - до 10 , що свідчить про не повну ліквідацію гнійно-запального процесу в клітковині середостіння.

У групі 1 лише в одному $(11,2 \%)$ випадку із 9 обстежених хворих ми вимушені були провести правобічну бокову торакотомію $з$ розкриттям середостіння у зв'язку із поширенням гнійнозапального процесу нижче біфуркації трахеї та появою гнійного випоту у правій плевральній порожнині. Інша динаміка захворювання спостерігалася у групі 2, де не використовували методику інтрамедіастинального введення антибактеріальних середників. Так, розвиток ГНМ діагностовано у $11(32,3 \%)$ iз 34 хворих, що вимагало проведення розширених оперативних втручань для ліквідації гнійного медіастиніту.

В основній групі хворих помер 1 (11,2\%) хворий, у якого спостерігали гнійно-некротичний розвиток процесу із швидким поширенням у всі відділи середостіння, сепсисом, наростаючою поліорганною недостатністю, швидким розвитком серцево-судинної недостатності. Не зважаючи на активну хірургічну тактику та інтесивну інфузійну терапію він помер на 3-ю добу від початку захворювання. Решта 8 хворих були виписані із стаціонару в задовільному стані в середньому на $21 \pm 3,4$ дня. В групі порівняння померло $5(41,6 \%)$ iз 12 хворих. Причинами летальності були пізнє звернення за медичною допомогою, сепсис, рефрактерний септичний шок, наростаюча поліорганна та серцево-судинна недостатність.

Висновки. 1. Застосування методу інтрамедіастинального введення антибактеріальних середників $є$ ефективним засобом попередження поширення гнійного процесу із міжфасціальних проміжків шиї у клітковину середостіння.

2. Використання запропонованого нами методу дозволяє знизити показники ендогенної інтоксикації вже на 2-у добу після операції, запобігає розвитку низхідного медіастиніту та дозволяє знизити летальність із $41,6 \%$ до $11,1 \%$.

Інформація про конфлікт інтересів. Автори заявляють про відсутність конфлікту інтересів при виконанні наукового дослідження та підготовці даної статті.

Інформація про фінансування. Автори гарантують, що вони не отримували жодних винагород в будь-якій формі, здатних вплинути на результати роботи.

Особистий внесок кожного автора у виконання роботи:

Сніжко С.С. - загальна ідея дослідження. 


\section{Список використаної літератури}

1. Gubin MA, Girko EI, Haritonov YuM. Diagnostika i lecheniie odontogennogo nediastinita. Vesnik hirurgii. 1996;3:12-15. [in Russian].

2. Slesarenko SS, Agapov VV, Prelatov VA Mediastenit. Moskva: Medpraktika. 2005;200. [in Russian].

3. Akallal N. Descending necrotizing mediastinitis: a diagnosis not to miss. Rev Pneumol Clin. 2002;58:355-8.

4. Alsoub HK, Chacko C. Descending necrotising mediastinitis. Postgrad Med J. 1995;71(832):98-101.

5. Naya Galvez MJ. Diffuse deep cervical infection. Report of three cases/ Acta Otorrinolaringol. Esp. 2000;51(2):183-7.

Стаття надійшла до редакції: 5.03.2018 p. 